\title{
Hiring Discrimination against Pro- Union Applicants: The Role of Union Density and Firm Size
}

\author{
Stijn Baerti, Eddy Omeyii
}

\begin{abstract}
We study the causal impact of revealing pro-unionism during the recruitment stage on hiring chances. To this end, we conduct a randomised field experiment in the Belgian labour market. When matched with employer and sector data, the experimentally gathered data enable us to test the heterogeneity of discrimination against pro-union applicants by the union density in the sector and the size of the firm. We find that disclosure of pro-unionism affects hiring chances in a negative way and that - in line with our expectations based on the literature - this negative impact is stronger in highly unionised sectors.
\end{abstract}

Keywords: trade unions; union density; hiring discrimination; randomised field experiments; industrial relations.

JEL:

J53;

$\mathrm{J} 71$;

C93.

\footnotetext{
*Authorisation: The present research was reviewed and approved by the Ethical Affairs Committee of the Faculty of Economics and Business Administration of Ghent University. Acknowledgements: We thank Niels Groothaert for his excellent research assistance. In addition, we are grateful to Sabien Dobbelaere, Glenn Rayp and Walter Van Trier for their useful comments and advice.

' Corresponding author. Ghent University, University of Antwerp, Université catholique de Louvain and IZA. SintPietersplein 6, B-9000 Gent, Belgium. Stijn.Baert@UGent.be. +32486492752.

ii Ghent University. Sint-Pietersplein 6, B-9000 Gent, Belgium. Eddy.Omey@UGent.be.
} 


\section{Introduction}

During the last several decades, economists have expressed a deep interest in studying employers' resistance to unionism and union organising. On the one hand, this managerial resistance may be, as argued by Dundon (2002), due to employers' ideological distaste of unionism and the different cultural attitudes between employers and unions toward, for instance, corporate identity, long hours, unpaid overtime and performance monitoring (Dundon, 2002). On the other hand, this opposition is related to the fact that employers see unions as interfering with their cost minimisation and profit maximisation goals. Based on a literature review on the relationship between unionism and economic performance by Hirsch (2004), the latter source of opposition seems to be rational to some extent: overall, it is found that profits and productivity growth are affected in a non-positive way by unionism. This is directly related to unions' success in bargaining for above-market wages or in capturing quasi-rents and may be indirectly mediated by the empirical finding that unionised employees are, on average, more often on sick leave and less job-satisfied than non-unionised employees (Freeman and Kleiner, 1999). ${ }^{1}$

On the one hand, this managerial opposition to unionism leads to strategic policy against unions as a whole with respect to employers. Former studies on labour-management disputes show how employers prevent unions from forming, weaken existing unions and apply pressure on unions during negotiations (see, for instance, Gall (2004) and Heery and Simms (2010) for the United Kingdom; Cooke (1985a, 1985b) and Lawler

\footnotetext{
${ }^{1}$ There are, however, some exceptions to this finding. See, for instance, the recent evidence on the effect of trade union activities on productivity in Japan provided by Morikawa (2010).
} 
and West (1985) for the United States).

On the other hand, also at the individual employee level, union membership and union activism may lead to unfavourable treatment by employers. Former research provides suggestive evidence for a negative impact of (disclosed) union affiliation on hiring chances, job tenure and wages (Cooke, 1985b; Leap et al., 1990; Redman et al., 1990; Saltzman, 1995; Servais, 1977; van den Broek, 2003). Most of these contributions rely on the qualitative analysis of unfair labour practices heard by national labour relation boards or the analysis of recruitment methods (designed to be antithetic to workplace unionism) and therefore do not provide a clear measure of discrimination based on union affiliation. The other studies are based on surveyed employee or employer perceptions on unequal treatment based on union affiliation. These researchers' results are inherently subjective and may be driven by the survey participants' goal to demonstrate the (non-)existence of discrimination. An exception is Saltzman (1995) matching data on real job applicants eager to vote for union representation with their hiring outcomes. Notwithstanding his ingenious research design, however, Saltzman's (1995) results also cannot be interpreted as causal because applicants who appear very similar based on the observable characteristics in the researcher's data except for their pro-union view may look very different with respect to employers in various aspects that are unobservable to the researcher but drive productivity (such as motivation and ability).

In this study, we are the first to estimate hiring discrimination against pro-union job candidates in a direct way. To this end, we conduct a field experiment in Flanders (i.e. the northern, Dutch-speaking part of Belgium) in which fictitious job applications of school-leavers are sent to real job openings. The fictitious applicants are randomised over the (treatment of) disclosure of the membership of the youth wing of a trade union. By monitoring the subsequent call-back by this disclosure, unequal treatment 
is identified directly and can be interpreted in a causal way. Because, by construction, the employer's entire decision making information is under our control, we are able to disentangle employer discrimination from all alternative explanations of heterogeneous hiring outcomes such as differences in human capital and differential employee preferences.

When matched with employer and sector data, the experimentally gathered data enable us to test two formerly established hypotheses in the context of individual union affiliation and labour market discrimination in a direct way. On the one hand, we test the hypothesis that unfavourable treatment of pro-union job applicants is higher in sectors where union density is high. Previous confrontations with trade unions in these sectors may encourage employers to try to prevent further strengthening of these unions. Moreover, employers in these sectors may have already found out that the probability of detection of unequal treatment is quite small. On the other hand, we hypothesise that discrimination against pro-union job applicants is higher in small firms. There are at least three reasons why this may be the case. First, larger companies are, on average, more likely to have a dedicated human resources department and standardised recruitment procedures. These more professional approaches to recruitment may result in a lower impact of individual recruiter preferences and - ipso facto - in a lower level of discrimination (irrespective of the discrimination ground). Second, in many countries, among which Belgium, small companies are not obliged to have union representation within (the company committee of) the firm. However, individual employees may try to enforce (formal or informal) union impact. Therefore, small companies may fear that recruiting pro-union employees might instigate union action within the firm. Third, related to the former reason, unions often have a much stronger position in large firms, which makes discrimination based on union membership riskier (Goerke and Pannenberg, 2011; Wauters et al., 2014; Wood et al., 2009; Woodhams 
and Lupton, 2006). ${ }^{2}$

The remainder of this article is structured in the following way. In the next section, we will provide the reader with a brief description of the institutional setting concerning trade unions in Belgium (and ipso facto in Flanders). In Section 3, we present the design of our randomised field experiment aimed at measuring labour market discrimination against prounion applicants on the one hand and testing the additional research hypotheses formulated in the former paragraph on the other hand. In Section 4, we present our research results based on a statistical examination of the experimentally gathered data. Finally, we present our conclusions regarding the research, as well as several limitations.

\section{Institutional Context}

Together with the Scandinavian countries, Belgium is characterised by a fairly high union density, i.e., a high share of union members among the wage and salary earners. In 2009, approximately $52 \%$ of employees were unionised. In contrast with most other European countries, this rate was quite stable during the last three decades (Liagre, 2012; Van Rie et al., 2011). Moreover, as summarised by Liagre (2012), union density is not significantly heterogeneous by age and firm size. On the other hand, union density varies by sector. It is the highest (higher than 70\%) in the sectors of agriculture, manufacture of wood, manufacture of fabricated metal products, electricity, gas and water supply, construction and water transport and the lowest (lower than 35\%) in the sectors of computer and

\footnotetext{
${ }^{2}$ From an empirical point of view, the latter hypothesis is confirmed in an indirect way by Goerke \& Pannenberg (2011) finding a negative effect of union membership on individual dismissals in large firms and by Woodhams and Lupton (2006) finding a positive effect of the presence of an HR professional at the firm, which is more common in large firms, on equality policies.
} 
related activities. An explanation for the high union density in Belgium, as provided by Van Rie et al. (2011), is the presence of the so-called Ghent system, i.e., a system of - in the case of Belgium, compulsory unemployment insurance that is subsidised by the public authorities but in which trade unions provide benefits to the unemployed.

Maybe even more importantly, the coverage rate, that is the rate of employers whose labour market situations are regulated by a collective agreement bargained by the union, is approximately 96\% (Ajzen, 2013). The Belgian industrial relations system can be described as both highly selforganising and highly structured (Fulton, 2011; Liagre, 2012; Omey, 2013). It is based on compromise between employer organisations and trade unions meeting each other at the national, sectoral and firm levels. The negotiations held in sectoral joint committees composed of representatives of employers active in the sector and the three most important trade union confederations (cf. infra) are important. These negotiations, about wages and labour conditions (quality of work), lead to collective labour agreements that are binding for all employers and employees in the industries covered by these committees (Ajzen, 2013; Liagre, 2012; Omey, 2013).

Abstracting from a few independent unions covering workers in particular Belgian regions, occupations and firms, Belgian trade unions are divided into three competing confederations. First, the "General Federation of Belgian Labour" is a Socialist trade union, (initially) inspired by Marxist theory and the related "Class conflict". The Socialist trade union is, more than the other two confederations, focussed on confrontation with employers and outspoken in its support of government interference via economic planning and control and of nationalisation of basic services. Second, the "Confederation of Christian Trade Unions" is linked to the Christian movement and - to some extent - to the Christian democratic political party. The Christian union aims, in the spirit of important Papal 
Social Encyclicals such as Rerum Novarum, at a peaceful cooperation between social classes. Third, the "General Confederation of Liberal Trade Unions" is linked to the Belgian Liberal party and is comparable to the Christian trade union in its aim of a peaceful cooperation between employers and employees (Liagre, 2012, Omey, 2013). The Liberal union, however, is more outspoken in its plea against outrageous government intervention. The market shares of the Socialist, Christian and Liberal trade unions amounted to approximately 41\%, 50\% and 9\%, respectively, in 2010 (Faniel and Vandaele, 2012).

The aforementioned confederations are comprised of several unions organised at the sectoral and/or occupational levels. The membership of a union is organised at this level (and not at the national level of the confederations). It is important for the remainder of the present study that all three aforementioned confederations have youth wings targeting student workers, graduates, interns, youth in part-time education and young employees. Members of the youth wing of a trade union (confederation) are automatically also members of the mother wing of this union. These members are perceived, at least by the contact people of the confederations we spoke with, as more committed compared to the "average" trade union member. The membership of the youth wing of a union is organised at the regional (i.e., Flemish or Walloon) level.

\section{The Experiment}

\subsection{Causal Evidence of Hiring Discrimination by means of a Field Experiment}

As mentioned in Section 1, and to the best of our knowledge, all former quantitative contributions to the literature on labour market discrimination 
against pro-union employees have been based on non-experimental data and, more concretely, on survey data. In general, these studies suffer from two important statistical problems that make a causal interpretation of their analyses problematic. Based on survey data, one might not be able to address the endogeneity of (disclosure of) union affiliation with respect to labour market chances. First, job candidates who appear similar to researchers (except for their union affiliation characteristics) based on standard non-experimental data may look very different to employers. No conclusive proof of unequal treatment can be provided by means of regressions on these data, as researchers cannot control all relevant variables taken into account by employers in making their hiring, remuneration and promotion decisions. Second, it is possible that individuals with better economic outcomes - who may be more confident in their interaction both with interviewers and colleagues - are more willing to disclose their pro-union position. This may lead to an upwards bias of the measured outcomes of pro-union candidates. Based on other assumptions, a downwards bias is also possible.

To overcome the mentioned methodological problems, in this study, we gather data through an experimental approach. Specifically, we conduct a field experiment in which, in the spirit of Bertrand and Mullainathan (2004) studying ethnic discrimination in the United States, fictitious job applications are sent to real job openings. These applications are assigned to the treatment of disclosure of pro-unionism in a random fashion. By monitoring the subsequent call-backs from the employer side, unequal treatment is identified in a direct way and can be given a causal interpretation. All supply side characteristics are, by construction, equal for treated and control candidates. Thereby, the finding of call-back that is statistically significantly more or less in favour of our pro-union applicants can only be due to disclosure of this membership.

More concretely, we conducted our experiment between October 2013 
and March 2014 in the Flemish labour market. Two applications of male job candidates with two years of relevant work experience, only differing in the characteristic that one indicated his membership in the youth wing of a trade union, were sent to 280 vacancies. These vacancies were randomly selected from the database of the Public Employment Agency of Flanders (VDAB), the region's major job search channel. We selected jobs in the private sector for two middle-low- and two middle-high-skilled occupations: operator, administrative clerk, industrial engineer and management assistant. We chose these particular occupations to obtain some variation in the selected vacancies' sectors.

\subsection{Construction of Fictitious Applications}

For each occupation in which we selected vacancies, we created two template applications comprised of a resume and a cover letter. We will refer to these applications as the "type A" and "type B" applications. These applications were equal in all productivity-relevant characteristics but differed in lay-out and details such as the particularly mentioned sports club. To ensure that our job applications were realistic and representative, example applications of the VDAB were used and calibrated for our purposes.

The type A and type B applicants were single males born, studying and living in comparable suburbs of Ghent, the second largest city of Flanders. These applicants graduated from secondary or tertiary education in June 2011 without any grade retention experience. The candidates applying for a job as an operator held a secondary education degree in mechanical maintenance, those applying for a job as an administrative clerk held a secondary education degree in commerce; those applying for a job as an industrial engineer, a Master's degree in industrial engineering; and those applying for a job as a management assistant, a Bachelor's degree in business administration. All of the applicants graduated from the same 
type of school, with a comparable reputation. Between August 2011 and October 2013 (the start of our experiment), the fictitious applicants were employed in an occupation equal to the one for which they applied in the experiment. A reason for the termination of their first job was not provided in the application.

Furthermore, we added to the type A and type B applications the following characteristics: Belgian nationality, Dutch mother tongue, driver's license, adequate English and French language skills and adequate IT skills. The cover letters indicated a person who was highly interested, motivated and organised. For the candidates applying for the jobs as an industrial engineer or as a management assistant, sport activities were also added. Last, we appended a fictitious postal address (based on real streets in middle-class neighbourhoods) and a date of birth to all application templates.

\subsection{Randomised Disclosure of Pro-unionism}

We sent two fictitious job applications, one of type $A$ and one of type $B$, to each selected vacancy. In one member of each pair (the "treated" member), the applicant indicated that he was a member of the youth wing of a Flemish trade union. This was done in the resume's "Other activities" section, in which it is common in Flanders to mention memberships. We opted for the membership of the youth wing of a union and not for the membership of the "mother" wing of the union for the following reason. In Flanders, as mentioned in Section 2, the membership of a classical trade union is related to the sector and/or occupation of the job in which one is employed. As a result, this membership might be (become) irrelevant when moving to another firm. Therefore, mentioning the membership of a classical trade union in the "Other activities" section of the resume would not have been realistic and would potentially have led to the detection of the experiment by some employers. In contrast, the membership of the 
youth wing of a trade union is, as mentioned in Section 2, organised at the regional (so Flemish) level and is not related to a particular job. Therefore, disclosing membership of such a youth wing in the "Other activities" section of the resume of a youth unemployed is (more) realistic. In addition, membership of the youth wing of a trade union is a stronger signal of union affiliation (or at least as unambiguous) than mother wing membership given that it cannot be prompted by motives related to the union's position in the provision of unemployment benefits (see Section 2) and given the relatively low fraction of workers affiliated with a youth wing. $^{3}$

In the other member of each pair (the "control" member), the applicant indicated that he was a member of a drama club. This was done to give both the treated and control candidates a signal of social engagement. By construction, we gave no direct indication of the control candidate's views towards unions. Therefore, this applicant could also have been a pro-union candidate not disclosing his membership. The comparison of treated candidates versus control candidates in our framework is therefore actually a comparison of "openly" union members on the one hand and candidates with an unrevealed view towards unions on the other hand. As a result, this comparison in fact captures the costs associated with disclosing union membership.

To eliminate any possible effect of the application type (A or B) on hiring outcomes, we alternately assigned the treatment of youth union membership to the type A and type B applications. As a result, the intended randomisation was realised by construction. In addition, we also alternated between the memberships of the three important (youth) trade unions of Belgium mentioned in Section 2. Subsequently, we sent the resulting combinations in an alternating order to the employers, each time

\footnotetext{
${ }^{3}$ For instance, the Flemish Socialist trade union had a membership of 699423 in 2010 while its youth wing had a membership of only 28285 .
} 
with approximately 24 hours in between.

\subsection{Definition of Positive Call-Back}

We registered two email addresses and mobile phone numbers: one for the pro-union individuals and one for the individuals not mentioning any trade union affiliation. All fictitious job applications were sent to the selected real vacancies by email. In view of avoiding detection, we applied to no more than one vacancy from the same employer. Call-backs were received by email or by telephone voicemail. As we mentioned postal addresses with non-existent street numbers in the applications, we could not measure reactions from the employer side by regular mail. However, several Flemish human resource managers confirmed that, currently, employers rarely invite job candidates to selection interviews by the latter channel. All reactions from the employer side received later than 30 days after sending out the applications were discounted.

In our analysis of the gathered data, we will distinguish between two definitions of positive call-back. Positive call-back in a strict sense is defined, in the spirit of Baert (Forthcoming), as the invitation for an interview concerning the job for which the fictitious candidate applied. Positive call-back in a broad sense includes, in addition to the former definition, the request to provide more information, the request to contact the employer or the proposal of an alternative job.

\section{Results}

\subsection{Do Employers Treat Pro-union Candidates Differently?}

Table 1 describes the experimentally gathered data. Overall, in 58 (99) of 
the 280 vacancies, at least one of both fictitious job candidates received a positive call-back in a strict sense (broad sense). 33 (67) cases resulted in an invitation (any positive reaction) for both the candidate not mentioning youth union membership and the candidate mentioning youth union membership, 18 (19) cases in an invitation for only the former candidate and 7 (13) cases in an invitation for only the latter candidate.

\section{TABLE 1 ABOUT HERE.}

The net discrimination rate is then calculated by (i) subtracting the number of applications for which the candidate mentioning union membership was preferred from the number of applications for which the candidate not mentioning union membership was preferred and (ii) dividing the result by the number of application pairs in which at least one candidate received a positive call-back. The result is a net measure of the number of discriminatory acts a pro-union applicant could expect to encounter per application for which at least one candidate received a positive call-back. At the level of the total sample, the net discrimination rate is 0.19 when adopting the strict definition of positive call-back. A standard $\chi^{2}$ test of the hypothesis that the candidates mentioning and not mentioning union membership were treated unfavourably equally often is rejected at the $5 \%$ significance level. The corresponding statistic for the broad definition of positive call-back, that is receiving any positive reaction, is 0.06 , which is not significantly different from 0 .

An alternative measure for unequal treatment, in the spirit of Bertrand and Mullainathan (2004), is the positive call-back ratio. This ratio is calculated by dividing the percentage of applications for which candidates not mentioning union membership received a positive call-back by the corresponding percentage for candidates mentioning youth union 
membership. The resulting ratio is 1.28 using the strict sense definition of positive call-back. This positive call-back ratio is significantly different from 1 at the 5\% significance level. This ratio's value indicates that the candidates in our experiment with no disclosed union affiliation received $28 \%$ more invitations for a job interview concerning the job for which they applied. Stated otherwise, pro-union candidates received $22 \%$ less invitations than their counterparts not mentioning union membership. ${ }^{4}$ The positive call-back ratio following the broad sense definition of positive call-back is 1.08 and not significantly different from 1.

Based on both the outlined net discrimination rate and the positive callback ratio, we conclude that there is evidence of unequal treatment against pro-union job candidates in the jobs for which we applied in the Flemish job market. We find, however, only unequal treatment with respect to the probability of getting an invitation for a job interview and not of getting any positive reaction. Additionally, taken together, these findings point in the direction of a preference for candidates not mentioning any union affiliation as the combination of these findings is partly the result of the fact that in $15 \%$ of the vacancies for which the prounion applicant gets only a positive call-back in the broad sense, the applicant not mentioning any union affiliation is immediately invited for a job interview.

\subsection{Is Unequal Treatment Heterogeneous by Union Density and Firm Size?}

To test whether unequal treatment is heterogeneous by the union density within the sector of the firm and by the size of this firm, the experimentally gathered data were matched with external statistics on these characteristics. This matching was realised by first looking up the company

${ }^{4} 0.22=1-1 / 1.28$. 
mentioned in the vacancy within the company database of the Flemish financial-economic magazine Trends (http://trendstop.knack.be). In this database, the sector of the firm could be found. The union density within the sector (at the 2-digit NACE 1.1 level) was proxied by its average number of unionised respondents in Round 1 to Round 5 (related to the period 2002-2010) of the European Social Survey. ${ }^{5}$ Based on the company number, which could also be found in this database of Trends, the firm size, proxied by the average number of workers in full-time equivalents in 2011, was looked up in the database of Bel-first (Bureau Van Dijk). Taking into account the missing values in the databases of Trends and Bel-first, we were able to construct the union density measure for $67 \%$ of the vacancies and the firm size measure for $59 \%$ of the vacancies.

The gathered variables on union density and firm size may correlate with other employer characteristics, so that descriptive analyses in the spirit of the ones presented in the former section based on subsamples of the data by union density within the sector of the firm and by the firm's size are not very informative. Therefore, we conduct a regression analysis in which we attempt to take into account potential confounders of the impact of union density and firm size on discrimination of pro-union candidates. In this respect, Schnabel (2013) shows that union density is positively related to the business cycle (i.e., growing procyclically), public sector employment and firm size. Given the short period of our experiment and the fact that we only selected vacancies in the private sector, the relationship between union density and discrimination against pro-union applicants we find may not be confounded with the correlation between union density on the one hand and business cycle and public nature of the sector on the other hand. However, Schnabel's (2013) evidence underlines the importance of including both union density and firm size within one

\footnotetext{
${ }^{5}$ This proxy was constructed and supplied by Guy Van Gyes (KU Leuven). NACE 1.1 refers to the Statistical Classification of Economic Activities in the European Community as revised in 2002.
} 
regression specification.

Table 2 and Table 3 present our regression results. We regress the outcome of positive call-back in a strict sense (Table 2) and in a broad sense (Table 3 ) on various sets of key and control variables by means of a linear probability model with resume fixed effects (controlling for random effects leads to the same conclusions). For reasons of comparability of the regression results, all explanatory variables that are interacted with "Union membership" are normalised by subtracting their mean among the population of candidates mentioning youth union membership and, for continuous variables, by dividing the result by their standard deviation among the same population. We do not include these variables without an interaction with disclosed youth union membership as they are constant at the resume type level and therefore controlled by our fixed-effects estimations. In what follows, we first focus on the results outlined in Table 2. Afterwards, we compare these results with the ones in Table 3.

TABLE 2 ABOUT HERE.

TABLE 3 ABOUT HERE.

First, in regression (1), we only include union membership disclosure as an explanatory variable. We find that revealing this membership lowers the chance of a job interview invitation by approximately 4 percentage points. Obviously, this outcome equals the difference between the positive callback rates in a strict sense among the treated and control candidates mentioned in Section 4.1.

Second, in regression (2), we interact union membership disclosure with the union density in the sector of the firm. We get, in line with the 
expectations outlined in Section 1, a significantly negative effect of this interaction variable on the probability of getting an invitation for a job interview. Increasing the union density within the sector with one standard deviation lowers the chance of an interview invitation by approximately 6 percentage points for pro-union candidates. In addition, by introducing this interaction variable - and ipso facto regressing on a smaller sample for which the union density variable could be constructed - the indicator variable for union membership disclosure becomes insignificant. In other words, based on this subsample of observations, we could not have rejected that overall the employers treated pro-union and control candidates equally.

Third, in regression models (3) and (4), we interact union membership disclosure with proxies of the firm size. In model (3), we adopt the natural logarithm of the average number of workers in full-time equivalents in 2011. In model (4), we follow the European Commission's division of firms in micro (less than 10 workers), small (10 or more workers but less than 50 workers) and (middle-)large firms (50 or more workers) by introducing a dummy capturing firms with 10 or more workers and a dummy capturing firms with 50 or more workers. As mentioned in Section 1, in Belgium a private firm is obliged to have union representation when this firm employs 50 or more workers. However, neither in column (3) nor in column (4) do we obtain significant effects for the firm size variables. The same is true when we adopt other specifications including quadratic terms or introducing dummies based on other firm size thresholds.

In regression (5), we combine the variables on union density and firm size included in regressions (2) and (3). Last, in regression (6), we extend regression model (5) with additional interaction variables capturing the occupation, the gender of the recruiter, the contract characteristics mentioned in the vacancy and the particular trade union mentioned in the application. These approaches lead to an even greater magnitude for the 
interaction between disclosed union membership and union density in the sector. In addition, no other interaction variables are significant. However, the relatively high standard errors of regression (6) may reflect a lack of statistical power, related to the relatively high number of included variables and the relatively small number of observations in this regression.

The same pattern of results is observed when using the positive callback in a broad sense as an outcome variable. However, one remarkable result in column (6) of Table 3 is that we obtain a lower chance on any positive reaction for pro-union candidates who reveal their affiliation with the Socialist trade union. This finding can be explained by the fact, mentioned in Section 2, that the Socialist union in Belgium is characterised, more than its Christian and Liberal counterparts, by a tradition of confrontation rather than of collaboration with employers.

\section{Conclusions}

We reported on the design and the results of a field experiment in which fictitious job applications with randomised disclosure of pro-unionism were sent to real job openings for operators, administrative clerks, industrial engineers and management assistants in Flanders. We found that, at least at the total sample level, the fictitious job candidates in our experiment who disclosed their membership of the youth wing of a labour member obtained $22 \%$ less invitations for a job interview. In addition, and in line with our theoretical expectations, our results showed that unfavourable treatment of pro-union candidates was more outspoken in sectors with high levels of union density. Last, we did not find any robust relation between the size of the job posting firm and its discriminatory behaviour.

We acknowledge several research limitations of this study. First, we test 
for unequal treatment only within the mentioned occupations and only within the jobs posted in the database of the Public Employment Agency of Flanders. It is possible that discrimination of pro-union candidates is more (or less) apparent in sectors other than those covered. However, as this limitation is expected to cause a similar shift in the discrimination measures in sectors with low and high union densities and for jobs of small and large firms, this should not bias the conclusions at the end of the previous paragraph.

Second, our experimental design is effective only in demonstrating potential unequal treatment in the initial stage of the recruitment process. Thereby, we cannot translate our research results into divergences in job offers and wages, let alone in job dismissals. However, Bertrand and Mullainathan (2004) argue that to the extent that the recruitment process has even important frictions, one would expect that reduced rates in first positive reactions would translate into reduced job offers and lower earnings. Moreover, for employers it seems to be rational to only invite candidates with a substantial probability of getting the posted job.

Third, for methodological reasons outlined in Section 3.3, we chose revealed membership of the youth wing of a trade union as a treatment, while the existing literature on the relationship between unionism on the one hand and economic performance and labour market discrimination on the other hand is related to classical trade unions and the "mother" wing membership. However, one should keep in mind that, as mentioned in Section 2, these youth members are automatically also members of the mother wing of the union. Moreover, we believe that revealed youth wing membership is a signal of union affiliation and union support - the signal with the effect that we wanted to estimate - that is at least as unambiguous as mother wing membership. Therefore, the treatment effects we present in this paper might serve as an upper bound for the effect of revealed classical union membership. 


\section{References}

Ajzen, M. (2013). Belgium: Industrial relations profile. Dublin: European Industrial Relations Observatory.

Baert, S. (2014). Career Lesbians. Getting Hired for Not Having Kids? Industrial Relations, 45, 543-561.

Bertrand, M., \& Mullainathan, S. (2004). Are Emily and Greg more employable than Lakisha and Jamal? A field experiment on labor market discrimination. American Economic Review, 94, 991-1013.

Cooke, W. N. (1985a). The Failure to Negotiate First Contracts: Determinants and Policy Implications. Industrial and Labor Relations Review, 38, 163-178.

Cooke, W. N. (1985b). The Rising Toll of Discrimination Against Union Activists. Industrial Relations, 24, 421-442.

Drydakis, N. (2009). Sexual orientation discrimination in the labour market. Labour Economics, 16, 364-372.

Dundon, T. (2002). Employer Opposition and Union Avoidance in the UK. Industrial Relations, 33, 234-245.

Faniel, J., \& Vandaele, K. (2012). Implantation syndicale et taux de syndicalisation (2000-2010). Courrier hebdomadaire, 2146.

Freeman, R. B., \& Kleiner, M. (1999). Do Unions Make Enterprises Insolvent. Industrial and Labor Relations Review, 52, 510-527.

Fulton, L. (2011). Worker representation in Europe. Brussels: European Trade Union Institute.

Gall, G. (2004). British Employer Resistance to Trade Union Recognition. Human Resource Management Journal, 14, 36-53.

Goerke, L., \& Pannenberg, M. (2011). Trade union membership and 
dismissals. Labour Economics, 18, 810-821.

Heery, E., \& Simms, M. (2010). Employer responses to union organizing: patterns and effects. Human Resource Management Journal, 20, 3-22.

Hirsch, B. T. (2004). What Do Unions for Economic Performance? Journal of Labor Research, 25, 415-455.

Lawler, J. J., \& West, R. (1985). Impact of Union-Avoidance Strategy in Representation Election. Industrial Relations, 24, 406-420.

Leap, T. L., Hendrix, W. H., Cantrell, R. S., \& Taylor, G. S. (1990). Discrimination Against Prounion Job Applicants. Industrial Relations, 29, 469-478.

Liagre, P. (2012). The Belgian case: an outlier in union density and membership. Mimeo.

Morikawa, M. (2010). Labor unions and productivity: An empirical analysis using Japanese firm-level data. Labour Economics, 17, 1030-1037.

Omey, E. (2013). Arbeid en Tewerkstelling. Ghent: Ghent University.

Redman, T., Snape, E., \& Bamber, G. J. (1990). Does Union Activity Damage Career Prospects? Implications For The Unionisation of Managers. Human Resource Management Journal, 1, 1-16.

Saltzman, G. M. (1995). Job Applicant Screening by a Japanese Transplant: A Union-Avoidance Tactic. Industrial and Labor Relations Review, 49, 88-104.

Schnabel, C. (2013). Union membership and density: Some (not so) stylized facts and challenges. European Journal of Industrial Relations, 19, 255-272.

Servais, J. M. (1977). Anti-union discrimination in the field of employment. International Labour Review, 115, 293-303.

van den Broek, D. (2003). Recruitment Strategies and Union Exclusion in 
Two Australian Call Centres. Relations Industrielles - Industrial Relations, $58,515-536$.

Van Rie, T., Marx, I., \& Horemans, J. (2011). Ghent revisited: Unemployment insurance and union membership in Belgium and the Nordic countries. European Journal of Industrial Relations, 17, 125-139.

Wauters, B., Mus, M., Lannoo, S., \& Devos, C. (2014). Perfect match or missing link? An analysis of the representativeness of trade union representatives in Belgium. Industrial Relations, 45, 424-442.

Wood, M., Hales, J., Purdon, S., Sejersen, T., \& Hayllar, O. (2009). A test for racial discrimination in recruitment practice in British cities. DWP Research Reports, no. 607.

Woodhams, C., \& Lupton, B. (2006). Gender-based equal opportunities policy and practice in small firms: the impact of HR professionals. Human Resource Management Journal, 16, 74-97. 
Table 1: The Probability of Positive Call-back: Net Discrimination Rates and Call-Back Ratios.

\begin{tabular}{|c|c|c|c|c|c|c|c|c|c|}
\hline & $\begin{array}{l}\text { Jobs } \\
\text { (No.) }\end{array}$ & $\begin{array}{c}\text { Neither candidate } \\
\text { positive call-back } \\
\text { (No.) }\end{array}$ & $\begin{array}{c}\text { Both candidates } \\
\text { positive call-back } \\
\text { (No.) }\end{array}$ & $\begin{array}{l}\text { Only candidate not } \\
\text { mentioning union } \\
\text { membership } \\
\text { positive call-back } \\
\text { (No.) }\end{array}$ & $\begin{array}{l}\text { Only candidate } \\
\text { mentioning union } \\
\text { membership } \\
\text { positive call-back } \\
\text { (No.) }\end{array}$ & NDR & $x^{2}$ & PCR & $t$ \\
\hline A. Positive call-back in strict sense & 280 & 222 & 33 & 18 & 7 & $0.190^{* *}$ & 4.840 & $1.275^{* *}$ & 2.213 \\
\hline B. Positive call-back in broad sense & 280 & 181 & 67 & 19 & 13 & 0.061 & 1.125 & 1.075 & 1.060 \\
\hline
\end{tabular}


Table 2: The Probability of Positive Call-back in Strict Sense: Regression Estimates.

\begin{tabular}{|c|c|c|c|c|c|c|}
\hline & (1) & (2) & (3) & (4) & (5) & (6) \\
\hline Union membership & $-0.039 * *(0.019)$ & $-0.028(0.020)$ & $-0.024(0.021)$ & $-0.024(0.021)$ & $0.025(0.023)$ & $0.027(0.022)$ \\
\hline Union membership $\mathrm{x}$ Union density in sector (normalised) & & $-0.059 * *(0.023)$ & & & $-0.078 * * *(0.027)$ & $-0.075^{* *}(0.030)$ \\
\hline Union membership x Log (average FTE at firm) (normalised) & & & $0.003(0.020)$ & & $0.008(0.026)$ & $0.011(0.028)$ \\
\hline Union membership x Average FTE at firm > 10 (normalised) & & & & $0.009(0.042)$ & & \\
\hline Union membership x Average FTE at firm > 50 (normalised) & & & & $0.001(0.064)$ & & \\
\hline Union membership x Occupation: operator (normalised) & & & & & & $0.033(0.068)$ \\
\hline Union membership x Occupation: clerk (normalised) & & & & & & $0.045(0.045)$ \\
\hline Union membership x Occupation: engineer (normalised) & & & & & & $-0.057(0.089)$ \\
\hline Union membership x Recruiter: male (normalised) & & & & & & $-0.045(0.046)$ \\
\hline Union membership x Temporary contract (normalised) & & & & & & $-0.002(0.045)$ \\
\hline Union membership x Part-time contract (normalised) & & & & & & $-0.057(0.059)$ \\
\hline Union membership $\times$ Socialist union (normalised) & & & & & & $-0.082(0.071)$ \\
\hline Union membership x Christian union (normalised) & & & & & & $-0.028(0.048)$ \\
\hline Constant & $0.182^{* * *}(0.009)$ & $0.134 * * *(0.010)$ & $0.115^{* * *}(0.011)$ & $0.115^{* * *}(0.011)$ & $0.125^{* * *}(0.012)$ & $0.125^{* * *}(0.012)$ \\
\hline Linear probability model & $x$ & $x$ & $x$ & $x$ & $x$ & $\mathrm{x}$ \\
\hline Dependent variable: invitation to a job interview & $\mathrm{x}$ & $\mathrm{x}$ & $\mathrm{x}$ & $\mathrm{x}$ & $\mathrm{x}$ & $\mathrm{x}$ \\
\hline Vacancy fixed effects & $x$ & $x$ & $x$ & $x$ & $x$ & $x$ \\
\hline Observations & 560 & 358 & 330 & 330 & 288 & 288 \\
\hline
\end{tabular}

Notes. See Section 4.2 for a definition of the variables adopted in the regressions. Except for "Union membership", all variables are normalised by subtracting their mean among the population of candidates mentioning youth union membership. Continuous variables are further normalised by dividing by their standard deviation among the same subpopulation. Standard errors, corrected for clustering at the vacancy level, are in parentheses. ${ }^{* * *}\left({ }^{* *}\right)((*))$ indicates significance at the $1 \%(5 \%)((10 \%))$ level. 
Table 3: The Probability of Positive Call-back in Broad Sense: Regression Estimates.

\begin{tabular}{|c|c|c|c|c|c|c|}
\hline & (1) & (2) & (3) & (4) & (5) & (6) \\
\hline Union membership & $-0.021(0.020)$ & $-0.028(0.023)$ & $-0.018(0.025)$ & $-0.018(0.025)$ & $-0.026(0.028)$ & $-0.023(0.026)$ \\
\hline Union membership $\mathrm{x}$ Union density in sector (normalised) & & $-0.041 * *(0.019)$ & & & $-0.054 * *(0.023)$ & $-0.043 *(0.025)$ \\
\hline Union membership $\mathrm{x}$ Log (average FTE at firm) (normalised) & & & $0.001(0.024)$ & & $-0.010(0.027)$ & $-0.009(0.030)$ \\
\hline Union membership x Average FTE at firm > 10 (normalised) & & & & $0.066(0.049)$ & & \\
\hline Union membership x Average FTE at firm > 50 (normalised) & & & & $-0.041(0.070)$ & & \\
\hline Union membership x Occupation: operator (normalised) & & & & & & $0.006(0.090)$ \\
\hline Union membership x Occupation: clerk (normalised) & & & & & & $0.067(0.066$ \\
\hline Union membership x Occupation: engineer (normalised) & & & & & & $-0.046(0.080)$ \\
\hline Union membership x Recruiter: male (normalised) & & & & & & $-0.065(0.053)$ \\
\hline Union membership x Temporary contract (normalised) & & & & & & $0.042(0.051)$ \\
\hline Union membership x Part-time contract (normalised) & & & & & & $0.024(0.089)$ \\
\hline Union membership $\times$ Socialist union (normalised) & & & & & & $-0.180 * *(0.071)$ \\
\hline Union membership $\mathrm{x}$ Christian union (normalised) & & & & & & $-0.077(0.062)$ \\
\hline Constant & $0.307^{* * *}(0.010)$ & $0.240 * * *(0.011)$ & $0.224^{* * *}(0.013)$ & $0.224 * * *(0.013)$ & $0.236 * * *(0.014)$ & $0.236 * * *(0.014)$ \\
\hline Linear probability model & $\mathrm{x}$ & $\mathrm{x}$ & $\mathrm{x}$ & $\mathrm{x}$ & $\mathrm{x}$ & $\mathrm{x}$ \\
\hline Dependent variable: any positive reaction & $\mathrm{x}$ & $\mathrm{x}$ & $\mathrm{x}$ & $\mathrm{x}$ & $\mathrm{x}$ & $\mathrm{x}$ \\
\hline Vacancy fixed effects & $\mathrm{x}$ & $\mathrm{x}$ & $x$ & $x$ & $x$ & $x$ \\
\hline Observations & 560 & 358 & 330 & 330 & 288 & 288 \\
\hline
\end{tabular}

Notes. See Section 4.2 for a definition of the variables adopted in the regressions. Except for "Union membership", all variables are normalised by subtracting their means among the population of candidates mentioning youth union membership. Continuous variables are further normalised by dividing by their standard deviation among the same subpopulation. Standard errors, corrected for clustering at the vacancy level, are in parentheses. ${ }^{* * *}\left({ }^{* *}\right)\left(\left({ }^{*}\right)\right)$ indicates significance at the $1 \%(5 \%)((10 \%))$ level. 